\title{
Evaluation of the organizational image of a university in a higher education institution
}

\section{Evaluación de la imagen organizacional universitariaen una institución de educación superior}

\author{
Juana Patlán Pérez $^{\mathrm{a}, *}$, Edgar Martínez Torres ${ }^{\mathrm{b}}$ \\ a Universidad Nacional Autónoma de México, Mexico \\ ${ }^{\mathrm{b}}$ Universidad Autónoma del Estado de Hidalgo, Mexico
}

Received 20 January 2015; accepted 28 January 2016

Available online 3 December 2016

\begin{abstract}
Organizational image is an important issue for many institutions of higher education by being immersed in a competitive environment that requires higher quality of educational services. The objective of this research is to evaluate the organizational image of an institution of higher education. For this purpose, an investigation was conducted. The stages of this research were: translation-retranslation of the original scale of organizational image; integration of scale items using a semantic differential response scale type; piloting of the scale with a sample of 226 teachers and 541 students of Autonomous University of Hidalgo State; determination of the psychometric properties of the scale (construct validity and reliability, and correlations between the factors of scale), descriptive statistics of the scale and comparative analysis. The results indicate that the organizational image scale adapted to Mexican population has adequate psychometric properties to assess this construct. In addition, we identified significant differences of the organizational image in each institute of the IES evaluated.

(C) 2016 Universidad Nacional Autónoma de México, Facultad de Contaduría y Administración. This is an open access article under the CC BY-NC-ND license (http://creativecommons.org/licenses/by-nc-nd/4.0/).
\end{abstract}

JEL classification: I23; C38; J24; L14

Keywords: Image; Organizational image; University organizational image

\footnotetext{
* Corresponding author.

E-mail address: patlanjuana@ hotmail.com (J. Patlán Pérez).
}

Peer Review under the responsibility of Universidad Nacional Autónoma de México. 


\section{Resumen}

La imagen organizacional es importante para muchas instituciones de educación superior por encontrarse en un entorno ampliamente competitivo que demanda servicios educativos de calidad. El propósito de estainvestigación fue evaluar la imagen organizacional universitaria en una institución de educación superior. Para este propósito se realizó una investigación de acuerdo con las siguieron etapas: adaptación de laescala de imagen organizacional a población mexicana; integración de escala en formato de diferencialsemántico; aplicación de la escala a una muestra de 226 profesores y 541 estudiantes de la UniversidadAutónoma del Estado de Hidalgo; determinación de las propiedades psicométricas de la escala (validez deconstructo y confiabilidad); estadísticas descriptivas de la imagen organizacional y análisis comparativo de laimagen organizacional por escuela. Los resultados indican que la escala de imagen organizacional adaptadaa población mexicana tiene propiedades psicométricas adecuadas para evaluar este constructo. Además, seidentificaron diferencias significativas de la imagen de la organización en cada instituto de la IES evaluada.

(C) 2016 Universidad Nacional Autónoma de México, Facultad de Contaduría y Administración. Este es un artículo Open Access bajo la licencia CC BY-NC-ND (http://creativecommons.org/licenses/by-nc-nd/4.0/).

Códigos JEL: I23; C38; J24; L14

Palabras clave: Imagen; Imagen organizacional; Imagen organizacional universitaria

\section{Introduction}

The organizational image is important for several organizations that want to be competitive and guarantee their permanence in the market in the short, medium and long term, with a growing demand for their products and/or services. The image perceived by the public and audiences of an organization, as well as by the employees, directly affects the efficient performance of the organizations (Druteikiene, 2011; McPherson \& Schapiro, 1998; Treadwell \& Harrison, 1994). In the higher education institutions (HEI), the organizational image is an important factor to attract and retain the best students, professors and employees (Helgesen \& Nesset, 2007; Polat, 2011). In the case of the students, the image of an educational institution is important for the realization of their studies; it gets the loyalty of the students and it is a means to attract other students (Brown \& Mazzarol, 2009). In regard to the professors and the personnel, the image of the educational institution is fundamental as it generates emotional ties, it creates a response as well as positive performance, it creates a greater commitment, involvement and cohesion in the personnel (Herrbach \& Mignonac, 2004; Traverso, 2005; Treadwell \& Harrison, 1994).

For the evaluation of the organizational image in literature, different measurement instruments are identified; these are used to measure, for example, the image of the police officers (Yim \& Schafer, 2009), the image of the schools, and the image of the universities and HEI of several countries (Gioia \& Thomas, 1996; Magierski and Kassouf, 2003; Baker and Brown, 2007; Helgesen \& Nesset, 2007). Furthermore, some studies that measure the organizational image through the perceptions of the directives (Herrbach \& Mignonac, 2004) and surgeons (Dukerich, Golden, \& Shortell, 2002), among others, are worth noting.

The evaluation of the organizational image of a university represents a challenge every time that the measuring instruments for the HEI become scarce. For this reason, it was considered relevant to carry out the evaluation of the organizational image of a HEI through the perceptions of the professors and students. The objective was to identify the perceptions that the internal public (professors and students) of a HEI have formed through their experience, information 
and interaction with the organization. For this purpose, the image scale of the organizational image of a university (cognitive and affective) of Beerli, Díaz, and Pérez (2002) and Russell and Pratt (1980) was adapted to the Mexican population. The methodology used in this research comprised five stages: (a) adaptation of the original scale in English to the Mexican population; (b) integration of the scale with a semantic differential type response format; (c) the use of the scale with a sample of 226 professors and 541 students of a HEI; (d) the determination of the psychometric properties of the scale (factor analysis and structural equation analysis, reliability analysis and the analysis of the correlations among factors); (e) the descriptive statistics and the analysis of the organizational image in the schools or the Institutes of the HEI that was evaluated.

Below we will analyze the conceptual foundations of the organizational image construct and of the organizational image of a university, as well as the components that comprise this construct. Subsequently, we describe the method used and present the results and conclusions of this investigation.

\section{Organizational image}

The organizational image is a complex construct based on the perception of the public or personnel of an organization that carries out a differentiating and comparative appraisal of its characteristics (Günalan \& Ceylan, 2014). The image alludes to the total impression that a person constructs in their mind regarding something or someone (Dichter, 1985). The image is formed for the people or for the public of the organization as a result of the interpretation that they make out of the information or disinformation of the organization (Toto \& García, 2012). However, the image involves the beliefs, attitude, stereotypes, ideas, relevant behavior and impressions that a person has of an object, a person or an organization (Kotler \& Andreasen, 2008).

The image is defined as the sum of the beliefs, ideas and impressions that a person has of an object. From a practical point of view, the image could be institutional or organizational. The institutional image is built as a group of people work to create an institution with regard to its objectives, working methods, the treatment they receive from the employees, which in conjunction turns into an institutional image that will indicate what the ethics or the organization are. On the other hand, the organizational image refers to the natural, spontaneous, or the resulting image of the expectations and the exchanges that the people have with the organization (Giangrande, 1995).

In turn, Polat (2011) defines the organizational image as the vision, representation or impression that the people form in their minds based on the information or data of an organization obtained through the interaction they have had with the elements or components of the organization. In this manner, the organizations that manage to attract talented human resources or clients, are those that maintain and communicate a positive image.

The organizational image is the shared knowledge that the people have of an organization and of how it should operate (Berg, 1985). The organizational image is also presented as the corporate image, perceived external prestige, corporate reputation, and corporate identity, among others (Helgesen \& Nesset, 2007). However, these constructs have differences, as shown in the following table (Tables 1 and 2).

The organizational image is defined by different authors with a focus, both in beliefs and in attitudes, in regard to an organization (Kotler, 1975). However, Treadwell and Harrison (1994) present a multifaceted perspective of the organizational image conceived as a group of cognitions, including beliefs, attitudes and impressions regarding the behaviors and relevant aspects of an 
Table 1

Definitions of constructs associated to the organizational image.

\begin{tabular}{ll}
\hline Construct & Definition \\
\hline Corporate image & They are the perceptions that different internal and external audiences have about \\
the organization (Chun, 2005). Involves the impressions that have insiders \\
(employees, managers) and outsiders (clients, suppliers). It is an indicator of the \\
client's trust on the organization (Huang \& Lien, 2012). \\
It refers to the perception that outsider people have of the image of an \\
organization. It describes the way outsider people interpret and evaluate an \\
organization's reputation based on experience, approach and the information \\
available about the organization (Herrbach \& Mignonac, 2004; Mael \& Ashforth, \\
1992). It also includes beliefs about how people outside the organization see it \\
(Dutton, Dukerich, \& Harquail, 1994). \\
It is the assessment made by different people (insiders and outsiders) about the \\
organization's ability to meet its expectations over time (Fombrun \& Van Riel, \\
2003). In general, it refers to public perceptions of the organization that are shared \\
by multiple people over time. \\
It refers to the common perception of what the organization does and how it \\
works, generating an identification of the people (insiders and outsiders) with the \\
organization, its goals and its achievements (Gioia \& Thomas, 1996). The \\
perception of the identity of an organization is captured by the organizational \\
image construct (Herrbach \& Mignonac, 2004). It is also defined as the perceived \\
meaning of the characteristics of the organization (Sartore-Baldwin \& Walker, \\
2011).
\end{tabular}

Source: Information based on several authors.

Table 2

Importance of the organizational image.

\begin{tabular}{|c|c|c|}
\hline Importance for & Authors & Importance of organizational image \\
\hline $\begin{array}{l}\text { Human } \\
\text { resources }\end{array}$ & $\begin{array}{l}\text { Herrbach and } \\
\text { Mignonac } \\
(2004)\end{array}$ & $\begin{array}{l}\text { - Workers' perceptions contribute to better performance. } \\
\text { - It has a significant effect on employee attitudes and behavior: } \\
\text { greater job satisfaction, organizational commitment, and } \\
\text { well-being at work. } \\
\text { - Attracts better-prepared candidates. } \\
\text { - Retains better performing employees. }\end{array}$ \\
\hline & $\begin{array}{l}\text { Traverso } \\
(2005)\end{array}$ & $\begin{array}{l}\text { - It is a factor attracting valuable human resources. } \\
\text { - It is an agglutinator and connecting element among the } \\
\text { members of the organization. }\end{array}$ \\
\hline External audience & $\begin{array}{l}\text { Nolan and } \\
\text { Harold (2010) }\end{array}$ & $\begin{array}{l}\text { - It is an important element of attraction of external audiences, } \\
\text { through instrumental attributes and symbolic meanings. }\end{array}$ \\
\hline
\end{tabular}

Source: Information based on several authors.

organization. In this sense, the organizational image represents an individual subjective response of a person in order to differentiate the organization with regard to metaphors, fantasies, myths or more structured cognitions such as diagrams or mental maps. According to Treadwell and Harrison (1994), the organizational image is the necessary result of a persuasive or planned communication that is frequently carried out one way and in a direct manner to a specific public or audience. The social-cognitive process to form the organizational image implies that any 
organization is capable of controlling the memory of the people, both internal and external, inducing them to forget negative images or images that are incompatible with their image, and in turn, to remember or highlight the positive events according to the vision and purposes of the organization.

For Duque and Carvajal (2015) the organizational image is described as a subjective knowledge, as an attitude and as a combination of the characteristics of the good or service that a company offers. However, the organizational image, according to these authors, is part of a set of individual perceptions about an organization, its characteristics, processes and products (goods and/or services) fabricated or produced. Thus, the organizational image is also identified by the ideas expressed by a society that has asymmetries and that is subject to the perception of the individuals, to the interest of each one of them, and to the roles that each person plays with regard to a specific organization (Blázquez \& Peretti, 2012).

\section{Organizational image of a university}

Nguyen and Leblanc (2001) define the organizational image of a university as the perceived image that the public has of a HEI according to their ideas, interests and personal experiences-social and historic. Under this definition, the person linked to the university does a rational and emotional assessment of the tangible and intangible attributes of the institution. In this manner, each person mentally forms an image of the institution, which could be different in each person that evaluates the institution. In turn, Guédez and Osta (2012) consider that the organizational image of a university refers to the image perceived by its external public (public and private organizations, graduates, governmental institutions) and internal public (current students, professors, administrative and services personnel, among others), who, according to their experience, interests and ideas carry out a rational, cognitive and emotional assessment of the characteristics and attributes of the institution.

Regarding HEIs, there are different studies about the organizational image of universities. Magierski and Kassouf (2003) present an analysis of the corporate image of five universities of Sao Pablo through the Familiarity-Favorability Matrix, with which it was possible to verify the knowledge and reputation of the universities for a particular public, the results of which could be used for the marketing planning of the universities.

In literature, there has been a broad interest regarding the election factors of a higher education institution for the pursuit of university studies. Among these factors are: gender, race, the institution where the high school studies were undertaken, social class, family influence on the students, the influence of their classmates and professors, and the image and reputation of the educational institution (Baker \& Brown, 2007).

The organizational image of a university is important for the correct functioning of a HEI, for the students and for the personnel of these types of institutions. As a summary, Table 3 shows the importance factors of the organizational image of a university for HEIs.

It is important to add that the HEIs should worry about the organizational image of a university for three main reasons (Torpor, 1983): (a) these types of institutions need to know how the institution is perceived with regard to its competition, (b) it is necessary to know how these institutions are perceived by their different audiences (students, ex-alumni, society), and (c) it is necessary to monitor the gap between real image and the desired or expected image. In consequence, the evaluation of the organizational image of a university is an important task. 
Table 3

Importance of the university organizational image.

\begin{tabular}{|c|c|c|}
\hline Importance for & Authors & Importance of university organizational image \\
\hline \multirow[t]{5}{*}{$\begin{array}{l}\text { Functioning and } \\
\text { competitiveness of the } \\
\text { university organization }\end{array}$} & $\begin{array}{l}\text { Treadwell and } \\
\text { Harrison } \\
(1994)\end{array}$ & $\begin{array}{l}\text { It contributes to the good functioning of the organization and } \\
\text { generates better results of the educational institution. }\end{array}$ \\
\hline & $\begin{array}{l}\text { McPherson } \\
\text { and Schapiro } \\
(1998)\end{array}$ & $\begin{array}{l}\text { It contributes to the competitiveness of the educational } \\
\text { institution, distinguishing it from its competitors, improving the } \\
\text { prestige and the educational quality. }\end{array}$ \\
\hline & $\begin{array}{l}\text { Druteikiene } \\
(2011)\end{array}$ & Image is a source of competitive advantage. \\
\hline & $\begin{array}{l}\text { Blázquez and } \\
\text { Peretti (2012) }\end{array}$ & It results in the sustainability of the organization \\
\hline & Helgesen and & It contributes to student loyalty. \\
\hline \multirow[t]{3}{*}{ Students } & Nesset (2007) & \\
\hline & $\begin{array}{l}\text { Stevens et al. } \\
(2008)\end{array}$ & $\begin{array}{l}\text { Generates positive results for students to recommend to the } \\
\text { educational institution. }\end{array}$ \\
\hline & Polat (2011) & $\begin{array}{l}\text { Student satisfaction is achieved through outstanding teachers, } \\
\text { good infrastructure, adequate resources and services. }\end{array}$ \\
\hline \multirow[t]{3}{*}{ Human resources } & $\begin{array}{l}\text { Treadwell and } \\
\text { Harrison }\end{array}$ & $\begin{array}{l}\text { It generates affective bonds between workers and the } \\
\text { organization. }\end{array}$ \\
\hline & (1994) & $\begin{array}{l}\text { It produces a positive response in the workers, generating } \\
\text { greater commitment and staff involvement. }\end{array}$ \\
\hline & $\begin{array}{l}\text { Nolan and } \\
\text { Harold (2010) }\end{array}$ & It attracts and retains the human resource to organizations. \\
\hline
\end{tabular}

Source: Information based on several authors.

\section{Components of the organizational image of a university}

Nguyen and Leblanc (2001) point out the presence of two components of the organizational image: functional and emotional. The functional component is related to the tangible characteristics of the organization that can be easily measured, in turn, the emotional component is related to psychological aspects such as feelings and attitudes toward the organization as a result of experiences and the processing of information of attributes that contribute to the performance of the organization.

Galiniené, Marcinskas, Miskinis, and Druteikiene (2009) identify different attributes of the organizational image, for example, the geographical location, the type of university (public or private), the complexity for admission and the educational level of the aspirants, the programs offered, the bibliographic repertory, the budget of the institution, the fees or tuition, etc. According to these authors, the ideal image of a HEI considers four factors (cognition, evaluation, activity and strengths) and eleven components: reliable, warmth, active, friendly, liberal, reputation, attractive, developing, young, modern and open.

In general, the definitions of organizational image take into consideration a cognitive element based on the group of perceived beliefs or attributes of the organization. However, there is a dimension that captures the feelings on the object that was evaluated. Beerli et al. (2002) state that the organizational image of a university is a perceptual phenomenon that is formed by an assessment and a rational and emotional interpretation made by the person with regard to the organization and, therefore, is comprised of an inextricable system of components: cognitive (beliefs) and affective (feelings, emotions). 
Meanwhile, Galiniené et al. (2009) state that the organizational image of a university is comprised by three components:

- Cognitive image. It alludes to the cognitions developed with regard to the facilities, the courses, the weather, the opportunities of enrollment, the enrollment fee, the professors, the quality of education, the preparation of the students, the theoretical-practical approach, the requirements of enrollment, the orientation or behavior toward the students, the communication or distance between the student or the professor, the relationship or distance between the university and society, the link of the university with companies, the number of students, the popularity of the university, the age of the university, and the type of university (elite, traditional, innovative).

- The emotional-affective image. It comprises emotions such as pleasant-unpleasant, boringstimulating, stressful-relaxed, somber-animated.

- General image. It refers to the positive or negative perception of an organization.

According to the points previously analyzed, it can be said that construction an organizational image is comprised by a cognitive and an affective component, all while taking into consideration the presence of global type indicators (Table 4).

Thus, the objective of this investigation was to evaluate the organizational image of a HEI through an adaptation for the Mexican population of the cognitive image scale of Beerli et al. (2002) and the affective image scale of Russell and Pratt (1980) for HEIs. Furthermore,

Table 4

Components of the university organizational image.

\begin{tabular}{|c|c|c|}
\hline Authors & Number & Components of the university organizational image \\
\hline $\begin{array}{l}\text { Nguyen and Leblanc } \\
\text { (2001) }\end{array}$ & 2 & $\begin{array}{l}\text { - Functional component. } \\
\text { - Emotional component }\end{array}$ \\
\hline Beerli et al. (2002) & 2 & $\begin{array}{l}\text { - Cognitive image (beliefs) } \\
\text { - Affective image (feelings, emotions) }\end{array}$ \\
\hline Galiniené et al. (2009) & 3 & $\begin{array}{l}\text { - Cognitive image } \\
\text { - Emotional-affective image } \\
\text { - General picture }\end{array}$ \\
\hline $\begin{array}{l}\text { Guerra and Arends } \\
\text { (2008) and } \\
\text { Traverso (2005) }\end{array}$ & 6 & $\begin{array}{l}\text { - Academic quality } \\
\text { - Social aspects } \\
\text { - Tangible elements } \\
\text { - Quality of service } \\
\text { - Accessibility } \\
\text { - Labor aspects }\end{array}$ \\
\hline $\begin{array}{l}\text { Nolan and Harold } \\
\text { (2010) }\end{array}$ & 2 & $\begin{array}{l}\text { - Instrumental attributes } \\
\text { - Symbolic meanings }\end{array}$ \\
\hline $\begin{array}{l}\text { Guédez and Osta } \\
\text { (2012) }\end{array}$ & 6 & $\begin{array}{l}\text { - Accessibility } \\
\text { - Quality of service } \\
\text { - Academic quality } \\
\text { - Tangible elements } \\
\text { - Social aspects } \\
\text { - Labor aspects }\end{array}$ \\
\hline
\end{tabular}

Source: Information based on several authors. 
in this research we identified the organizational image of a university as perceived by each school.

\section{Method}

\section{Planning and research question}

The organizational image is relevant for the organizations and, particularly, for the HEIs. The demand to pursue university studies is influenced by the university image, as the attraction and retention of professors and employees is affected by the image held by the institution. Furthermore, the organizational image is important because it is a basic element in the strategic direction, an attraction factor for organizations and a consolidating and cohesive factor for the members of the organization (Traverso, 2005).

As indicated by Perozo and Alcalá (2008) the image is important for both the source of the image (organization) as well as for who receives it (the subject). For the organization, a positive image is a requirement to establish a positive-favorable relationship with a target audience, whereas for the subject the image is a means of considering or evaluating the organization (good, bad, useful, useless, etc.). Thus, the greater the trust placed on an organization's image by a subject, the more important it will be that the organization has a solid reputation. In this sense, it was considered relevant to carry out an investigation with the objective of understanding which is the organizational image perceived of the Autonomous University of the State of Hidalgo, by both its professors and students, as well as to identify the significant differences that exist in the image perceived in each Institute of the evaluated HEI.

\section{Investigation type and design}

An ex-post facto investigation of the descriptive and variable association type was carried out. A non-experimental design was used.

\section{Sample}

The sample was comprised of 541 (70.5\%) degree students and $226(29.5 \%)$ full-time professors of a HEI (Table 1). The average age of the sample was of 27.2 years, $51.0 \%$ were women and $49.0 \%$ men. Of the sample, $24.5 \%$ correspond to the Institute of Economic Administrative Sciences, $20.0 \%$ to the Institute of Basic Sciences and Engineering, $19.3 \%$ to the Institute of Health Sciences, $15.9 \%$ to the Institute of Social Sciences and Humanities, $11.5 \%$ to the Arts Institute, and $8.2 \%$ to the Institute of Agricultural Sciences.

\section{Instrument}

For the measurement of the cognitive image, 21 reactants were used in a semantic differential scale comprised by bipolar procedures with five points of response $(5,4,3,2,1)$, which was developed by Beerli et al. (2002) for HEI. The global organizational image indicated built by the aforementioned authors was also utilized, corresponding to a reactant. For the measurement of the affective image, three reactants developed by Russell and Pratt (1980) for HEI were utilized and 
previously validated by Beerli et al. (2002). The measurement instrument and the final reactants of the scale are presented in Appendix 1.

\section{Procedure}

The methodology used consisted on seven stages: (a) adaptation of the original scale in English of Beerli et al. (2002) and Russell and Pratt (1980) through a translation-retranslation process carried out by two experts in organizational evaluation and psychometry; (b) integration of the scale and the reactants, in this case the reactants were comprehensible and congruent for the Mexican population and the response format was of the semantic differential type with five points of response between the pairs of adjectives of the scale; (c) implementation of the scale to a sample of 226 professors and 541 students of a HEI; d) determination of the psychometric properties of the scale (factorial analysis and analysis of the structural equations, reliability analysis, and analysis of the correlations between factors); (e) descriptive statistics of the organizational image and comparative analysis per school.

\section{Data analysis}

The construct validity was carried out through the exploratory factorial analysis using the SPSS software version 17 and the analysis of structural equations with the AMOS software version 20. In order to determine the reliability of the scale, Cronbach's Alpha was estimated; furthermore, descriptive statistics of the factors of the scale were carried out and the Pearson correlation coefficients were determined between the factors of the scale. In order to identify the relations statistically significant between the factors of the organizational image and the different Institutes of the evaluated HEI, a one track variance analysis was carried out.

\section{Results and discussion}

The adaptation process of the organizational image scale of Beerli et al. (2002) and Russell and Pratt (1980) was done through a translation and retranslation process of the reactants of the original scale in English with the collaboration of two experts in organizational evaluation and psychometry. In this process, the original meaning of the reactant was maintained. Subsequently, the reactants of the scale were integrated in such a way for them to be comprehensible and congruent for the Mexican population. A total of 23 reactants were integrated (19 reactants for the cognitive Image, 3 reactants for the affective image, and 1 reactant for the global Indicator), which had a response scale of the semantic differential type with five points of response between the pairs of bipolar adjectives of the scale. The implementation of the scale was carried out with a sample of 226 professors and 541 students of a HEI of Mexico.

Table 5 shows the construct validity results of the Organizational Image Scale for a University carried out through the exploratory factorial analysis with the method of main components and varimax rotation. The results show the presence of three cognitive image factors (F Orientation and university training, F2 Reputation of the institution, F3 Institutional maturity) and an affective image factor (F4). The percentage of accumulated explained variance was of $70.35 \%$, with a percentage of explained variance of $21.97 \%$ for the first factor, $18.85 \%$ for the second, $14.86 \%$ for the third, and $16.67 \%$ for the fourth. In these results, a value of .889 was obtained 
Table 5

Factor analysis of the University Organizational Image Scale.

\begin{tabular}{|c|c|c|c|c|}
\hline Item & $\begin{array}{l}\text { F1 cognitive } \\
\text { image: } \\
\text { orientation and } \\
\text { university } \\
\text { preparation }\end{array}$ & $\begin{array}{l}\text { F2 cognitive } \\
\text { image: } \\
\text { reputation of the } \\
\text { institution }\end{array}$ & $\begin{array}{l}\text { F3 cognitive } \\
\text { image: } \\
\text { institutional } \\
\text { maturity }\end{array}$ & $\begin{array}{l}\mathrm{F} 4 \\
\text { affective } \\
\text { image }\end{array}$ \\
\hline 1. The teaching of teachers is good/bad & 0.675 & 0.082 & 0.072 & 0.507 \\
\hline 2. Education is good/bad & 0.675 & 0.142 & 0.061 & 0.486 \\
\hline $\begin{array}{l}\text { 3. Teachers are very demanding/not very } \\
\text { demanding }\end{array}$ & 0.699 & 0.096 & 0.152 & 0.011 \\
\hline 4. Student-centered/non-student-centered & 0.775 & 0.268 & 0.197 & 0.074 \\
\hline 5. Close to students/away from students & 0.770 & 0.234 & 0.187 & 0.117 \\
\hline 6. Innovative/traditional university & 0.432 & 0.448 & 0.343 & 0.183 \\
\hline 7. Updated/not updated university & 0.264 & 0.658 & 0.343 & 0.152 \\
\hline 8. It has a good prestige/bad prestige & 0.179 & 0.872 & 0.159 & 0.192 \\
\hline 9. Has a good reputation/bad reputation & 0.178 & 0.840 & 0.102 & 0.290 \\
\hline 10. It has good facilities/bad facilities & 0.271 & 0.128 & 0.749 & 0.184 \\
\hline $\begin{array}{l}\text { 11. With a wide variety of educational } \\
\text { programs/with few educational programs }\end{array}$ & 0.109 & 0.270 & 0.777 & 0.067 \\
\hline 12. The environment is good/bad & 0.160 & 0.124 & 0.633 & 0.502 \\
\hline 13. Stimulating/boring institution & 0.182 & 0.433 & 0.255 & 0.716 \\
\hline 14. Relaxing/stressful institution & 0.137 & 0.291 & 0.215 & 0.767 \\
\hline Percentage of variance explained & 21.97 & 18.85 & 14.86 & 16.67 \\
\hline Percentage of cumulative explained variance & 21.97 & 40.82 & 55.69 & 70.35 \\
\hline $\begin{array}{l}\text { Kaiser-Meyer-Olkin measure of sampling } \\
\text { adequacy }\end{array}$ & .889 & & & \\
\hline Bartlett's test of sphericity & 5929.49 & & & \\
\hline$p$ & .000 & & & \\
\hline
\end{tabular}

Source: Own elaboration based on the results of the research. Note: Method: main components; Rotation: Varimax; $n=767$.

in the Kaiser-Meyer-Olkin sample suitability measurement and of 5929.49 in the Bartlett's sphericity test $(p=.000)$ which indicates the adequacy of the factorial analysis. In total, 7 reactants were eliminated from the cognitive image factors and one reactant from the affective image factors.

Likewise, the factorial structure of the organizational image scale for a university was identified through the analysis of structural equations. To this end, two models were designed. Model 1 includes three cognitive image factors (F1 Orientation and university training, F2 Reputation of the institution, F3 Institutional maturity) and an affective image factor (F4 affective image). The results of Model 1 are shown in Figure 1. The standardized beta values of each reactant with its respective factors oscillated between .560 and .930 . Furthermore, the correlations between the three cognitive image factors oscillated between .583 and 661 .

Figure 2 shows the results of Model 2. In these results, three cognitive image factors and one affective image factor were identified. The relation of factors 1, 2 and 3 with the cognitive image oscillated between .763 and .823 . The correlation between the cognitive image and the affective image gave a value of .846 . As for the standardized beta values of the reactants, each factor oscillated between .555 and .939 . 


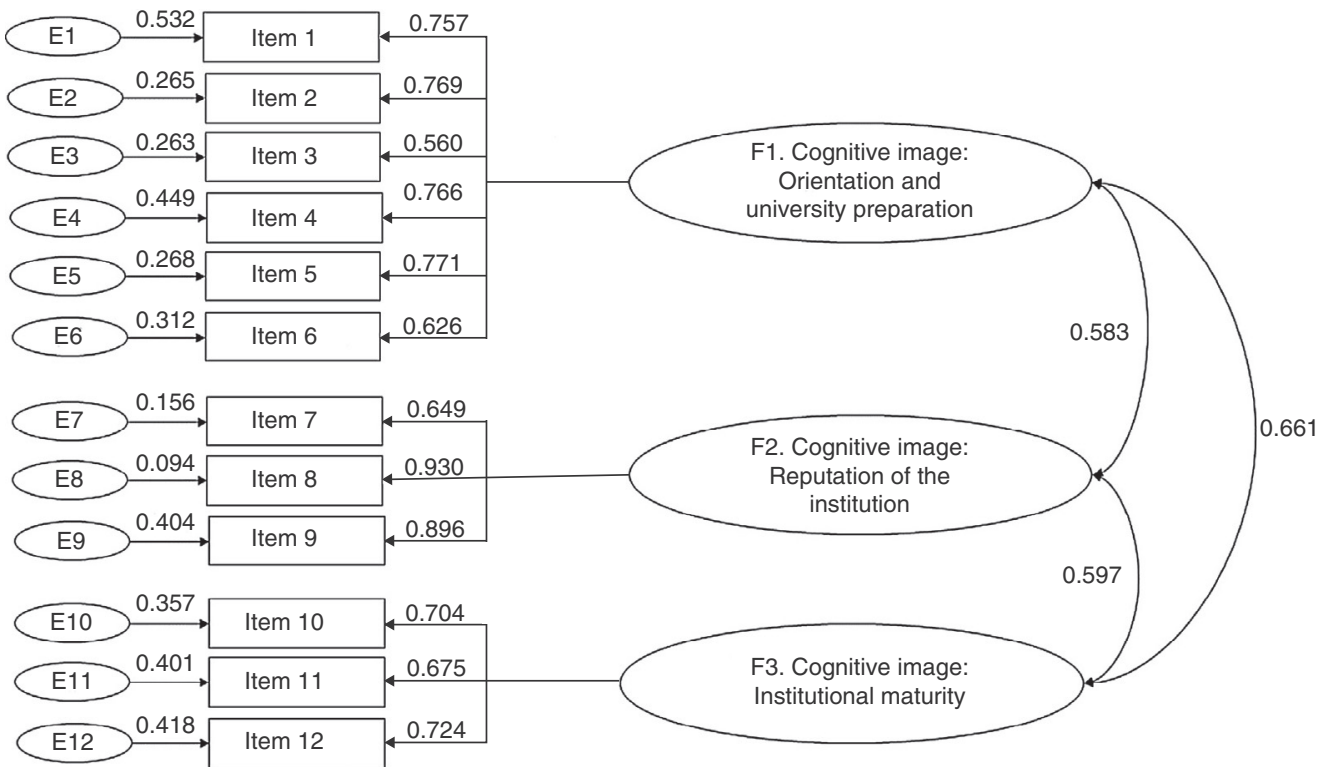

Figure 1. Factorial analysis of the university organizational image: Model 1.

Source: Own elaboration based on the results of the research.

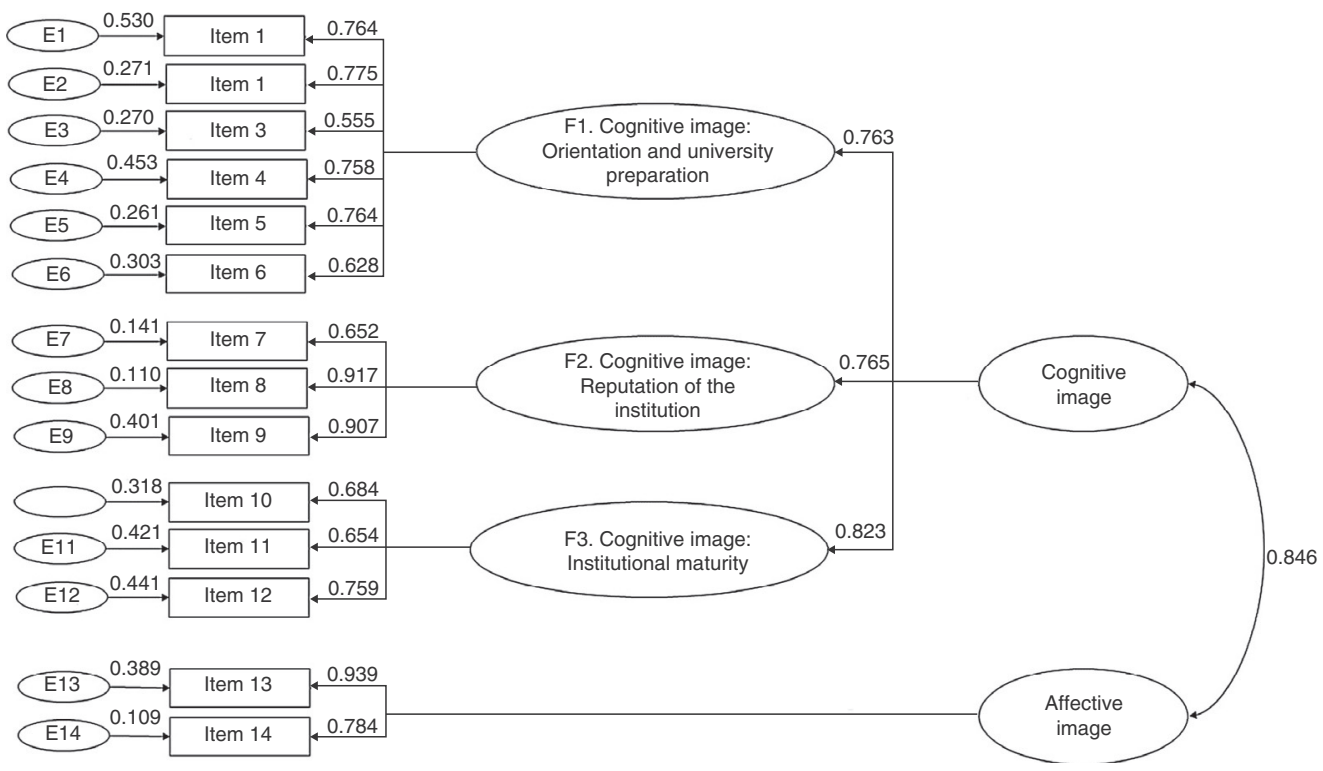

Figure 2. Factorial analysis of the university organizational image: Model 2.

Source: Own elaboration based on the results of the research.

Table 6 shows the results of the adjustment measures, of incremental adjustment and parsimonious adjustment of models 1 and 2, the results of which were shown previously. Model 2, which includes three cognitive image factors and one affective image factor, provides better adjustment levels (add formula) in comparison with Model 1. These results confirm the presence of four 
Table 6

Adjustment measures of the factor analysis models of the University Organizational Image Scale.

\begin{tabular}{|c|c|c|}
\hline Adjustment measures & $\begin{array}{l}\text { Model } 1 . \\
\text { Cognitive image: } \\
3 \text { factors }\end{array}$ & $\begin{array}{l}\text { Model } 2 . \\
\text { Cognitive image: } \\
3 \text { factors; affective } \\
\text { image: } 1 \text { factor }\end{array}$ \\
\hline \multicolumn{3}{|l|}{ Absolute } \\
\hline$X^{2}$ & 69.606 & 703.044 \\
\hline $\mathrm{gl}$ & 51 & 73 \\
\hline$p$ & .000 & .000 \\
\hline GFI & .882 & .893 \\
\hline RMSEA & .120 & .106 \\
\hline ECVI & .898 & 1.038 \\
\hline \multicolumn{3}{|l|}{ Incremental } \\
\hline TLI & .846 & .866 \\
\hline NFI & .872 & .882 \\
\hline CFI & .881 & .893 \\
\hline \multicolumn{3}{|l|}{ Parsimonious } \\
\hline PNFI & .674 & .708 \\
\hline PGFI & .681 & .716 \\
\hline CMIN/GL & 11.953 & 703.044 \\
\hline AIC & 687.606 & 795.044 \\
\hline
\end{tabular}

Source: Own elaboration based on the results of the research.

Note: $n=767$.

factors in the organizational image scale: three factors corresponding to the cognitive image (Orientation and university training, reputation of the institution, and institutional maturity) and one factor corresponding to the affective image.

The descriptive statistics of the reactants that comprise the Organizational Image Scale for a University are shown in Table 7. All the reactants showed statistically significant correlations with their respective factor and with the total of the scale, with significant correlations (add formula) that oscillated between $r=.528$ and $R=.772$.

The results of the reliability analysis presented values of Cronbach's Alpha above .70 (Table 8). In the three cognitive image factors these indicators were above .80 and in the affective image factor Cronbac's Alpha was of $\alpha=.744$. The global scale that includes the 14 validated reactants showed a Cronbach's Alpha of $\alpha=.910$.

Table 9 shows the descriptive results of the organizational image. The highest average score was identified in the F2 Reputation of the institution (average $=3.59$ ), whereas the lowest score was in the global indicator of the organizational image (average $=3.19$ ).

Furthermore, significant correlations were found between the four factors of the Scale of Organizational Image, which oscillated between $r=.512$ and $R=.597$ (add formula). With the global indicator of organizational image F4 Affective image having the highest significant correlation (add formula) (Table 10).

Once the factorial structure and the reliability of the Organizational Image Scale for a University were obtained, the factors were defined as shown in Table 11.

With the previously mentioned results, a total of 14 reactants were obtained that measure four factors of the organizational image of a university (three cognitive image factors and one affective image factor). The organizational image scale for a university is shown in Appendix 1. 
Table 7

Descriptive statistics and correlations of the items of the University Organizational Image Scale.

\begin{tabular}{|c|c|c|c|c|c|c|}
\hline Items & Mean & Median & $\mathrm{SD}$ & $\begin{array}{l}\text { Correlation } \\
\text { with factor }\end{array}$ & $\begin{array}{l}\text { Total } \\
\text { correlation }\end{array}$ & $\begin{array}{l}\text { Alpha if item } \\
\text { is removed }\end{array}$ \\
\hline \multicolumn{7}{|c|}{ F1 cognitive image: orientation and university preparation } \\
\hline Item 1 & 3.52 & 4.00 & 0.86 & $.790^{* *}$ & $.685^{* *}$ & .821 \\
\hline Item 2 & 3.56 & 4.00 & 0.81 & $.797^{* *}$ & $.700^{* *}$ & .819 \\
\hline Item 3 & 3.39 & 3.00 & 0.81 & $.667^{* *}$ & $.528^{* *}$ & .850 \\
\hline Item 4 & 3.40 & 3.00 & 0.79 & $.805^{* *}$ & $.695^{* *}$ & .816 \\
\hline Item 5 & 3.40 & 3.00 & 0.81 & $.806^{* *}$ & $.689^{* *}$ & .816 \\
\hline Item 6 & 3.32 & 3.00 & 0.94 & $.707^{* *}$ & $.715^{* *}$ & .849 \\
\hline \multicolumn{7}{|c|}{ F2 cognitive image: reputation of the institution } \\
\hline Item 7 & 3.47 & 4.00 & 0.84 & $.809^{* *}$ & $.709^{* *}$ & .912 \\
\hline Item 8 & 3.66 & 4.00 & 0.83 & $.923^{* *}$ & $.711^{* *}$ & .708 \\
\hline Item 9 & 3.63 & 4.00 & 0.89 & $.909^{* *}$ & $.716^{* *}$ & .749 \\
\hline \multicolumn{7}{|c|}{ F3 cognitive image: institutional maturity } \\
\hline Item 10 & 3.33 & 3.00 & 0.91 & $.820^{* *}$ & $.642^{* *}$ & .661 \\
\hline Item 11 & 3.64 & 4.00 & 0.86 & $.805^{* *}$ & $.583^{* *}$ & 667 \\
\hline Item 12 & 3.49 & 4.00 & 0.87 & $.814^{* * *}$ & $.668^{* * *}$ & .650 \\
\hline \multicolumn{7}{|c|}{ F4 affective image } \\
\hline Item 13 & 3.42 & 3.00 & 0.96 & $.928^{* *}$ & $.772^{* *}$ & - \\
\hline Item 14 & 3.24 & 3.00 & 1.00 & $.935^{* *}$ & $.685^{* * *}$ & - \\
\hline \multicolumn{7}{|c|}{ Global indicator of university organizational image } \\
\hline Item 15 & 3.47 & 3.00 & 0.95 & & $.690^{* *}$ & - \\
\hline
\end{tabular}

Source: Own elaboration based on the results of the research.

Note: $n=767$.

** $p \leq .01$.

Table 8

Reliability coefficients of the University Organizational Image Scale.

\begin{tabular}{llr}
\hline Factor & Cronbach's alpha & Number of items \\
\hline F1. Cognitive image: orientation and university preparation & .853 & 6 \\
F2. Cognitive image: reputation of the institution & .855 & 3 \\
F3. Cognitive image: institutional maturity & .847 & 3 \\
F4. Affective image & .744 & 2 \\
Global (14 items) & .910 & 14
\end{tabular}

Source: Own elaboration based on the results of the research.

Note: $n=767$.

Regarding the comparative analysis of the organizational image perceived in each of the Institutes of the evaluated HEI, significant differences were identified in all the considered factors of organizational image, taking into account the six Institutes that comprise the evaluated HEI.

Table 12 shows the results of the analysis of variance. In order to identify the differences between the group of averages, the Tukey test was carried out, the results obtained from this test are shown in Table 12. These results indicate that the image regarding the orientation and 
Table 9

Statistics of the University Organizational Image Scale.

\begin{tabular}{lllllll}
\hline Factor & Mean & Median & Mode & SD & Minimum & Maximum \\
\hline F1. Cognitive image: Orientation and university preparation. & 3.43 & 3.33 & 3.00 & 0.64 & 1.00 & 5.00 \\
F2. Cognitive image: Reputation of the institution & 3.59 & 3.67 & 4.00 & 0.75 & 1.00 & 5.00 \\
F3. Cognitive image: Institutional maturity & 3.49 & 3.66 & 4.00 & 0.72 & 1.00 & 5.00 \\
F4. Affective image & 3.33 & 3.50 & 3.00 & 0.91 & 1.00 & 5.00 \\
Global indicator of university organizational image & 3.46 & 3.00 & 3.00 & 0.59 & 1.00 & 5.00 \\
\hline
\end{tabular}

Source: Own elaboration based on the results of the research.

Note: $n=767$.

Table 10

Pearson correlation coefficients among the factors of the University Organizational Image Scale.

\begin{tabular}{llllllll}
\hline Factors of the University Organizational Image Scale & F1 & F2 & F3 & F4 & Global indicator \\
\hline F1. Cognitive image: orientation and university preparation & 1 & & & & & & \\
F2. Cognitive image: reputation of the institution & $.575^{* *}$ & 1 & & & & \\
F3. Cognitive image: institutional maturity & $.543^{* *}$ & $.534^{* *}$ & 1 & & & \\
F4. Affective image & $.554^{* *}$ & $.597^{* *}$ & $.548^{* *}$ & 1 & \\
Global indicator of university organizational image & $.512^{* *}$ & $.579^{* *}$ & $.531^{* *}$ & $.719^{* *}$ & 1
\end{tabular}

Source: Own elaboration based on the results of the research.

Note: $n=767$.

** $p \leq .01$.

Table 11

Definition of factors of the University Organizational Image Scale.

\begin{tabular}{|c|c|}
\hline Variable & Factors \\
\hline $\begin{array}{l}\text { Cognitive image. } \\
\text { Set of cognitions developed by a } \\
\text { person internal or external to the } \\
\text { organization regarding the } \\
\text { orientation and university preparation } \\
\text { of the HEI, its reputation and } \\
\text { institutional maturity. }\end{array}$ & $\begin{array}{l}\text { F1. Orientation and university preparation. Perceived image } \\
\text { regarding attributes related to the orientation of the university } \\
\text { toward students, society, as well as the preparation that provides to } \\
\text { the students. } \\
\text { F2. Reputation of the institution. Perceived image of the prestige } \\
\text { and reputation of the educational institution and its level of } \\
\text { updating. } \\
\text { F3. Institutional maturity. Perceived image about the institution's } \\
\text { degree of maturity with respect to its facilities, educational } \\
\text { programs and environment. }\end{array}$ \\
\hline $\begin{array}{l}\text { Affective image. } \\
\text { Set of positive or negative emotions }\end{array}$ & $\begin{array}{l}\text { F4. Affective image. Set of emotions expressed with respect to an } \\
\text { HEI: stimulating-boring and relaxing-stressful. }\end{array}$ \\
\hline
\end{tabular}
expressed by internal and external members of an organization.

Source: Own elaboration based on the results of the research.

university training $(F=2.195 ; p=.050)$ is significant and is perceived at a higher level in the Institute of Health Sciences (average $=3.53$ ), most probably because it deals with an Institute that excels in the general surgeon career, that due to its tradition generates graduates with a high academic level. 
Table 12

Organizational image by school (results of one-way analysis of variance).

\begin{tabular}{|c|c|c|c|c|c|c|c|}
\hline Factor & Institute & $n$ & Median & SD & $F$ & $p$ & Tukey's test \\
\hline $\begin{array}{l}\text { F1. Cognitive image: } \\
\text { Orientation and university } \\
\text { preparation }\end{array}$ & $\begin{array}{l}\text { 1. CEA } \\
\text { 2. A } \\
\text { 3. CBI } \\
\text { 4. CSHU } \\
\text { 5. CSA } \\
\text { 6. CAP } \\
\text { Total }\end{array}$ & $\begin{array}{r}188 \\
88 \\
158 \\
122 \\
148 \\
63 \\
767\end{array}$ & $\begin{array}{l}3.33 \\
3.34 \\
3.46 \\
3.48 \\
3.53 \\
3.45 \\
3.43\end{array}$ & $\begin{array}{l}0.65 \\
0.57 \\
0.57 \\
0.71 \\
0.68 \\
0.56 \\
0.64\end{array}$ & 2.195 & .050 & $1 / 5$ \\
\hline $\begin{array}{l}\text { F2. Cognitive image: } \\
\text { Reputation of the } \\
\text { institution }\end{array}$ & $\begin{array}{l}\text { 1. CEA } \\
\text { 2. A } \\
\text { 3. CBI } \\
\text { 4. CSHU } \\
\text { 5. CSA } \\
\text { 6. CAP } \\
\text { Total }\end{array}$ & $\begin{array}{r}188 \\
88 \\
158 \\
122 \\
148 \\
63 \\
767\end{array}$ & $\begin{array}{l}3.62 \\
3.25 \\
3.68 \\
3.62 \\
3.67 \\
3.46 \\
3.59\end{array}$ & $\begin{array}{l}0.70 \\
0.82 \\
0.66 \\
0.83 \\
0.73 \\
0.81 \\
0.75\end{array}$ & 5.119 & .000 & $2 / 1,3,4,5$ \\
\hline $\begin{array}{l}\text { F3. Cognitive image: } \\
\text { Institutional maturity }\end{array}$ & $\begin{array}{l}\text { 1. CEA } \\
\text { 2. A } \\
\text { 3. CBI } \\
\text { 4. CSHU } \\
\text { 5. CSA } \\
\text { 6. CAP } \\
\text { Total }\end{array}$ & $\begin{array}{r}188 \\
88 \\
158 \\
122 \\
148 \\
63 \\
767\end{array}$ & $\begin{array}{l}3.56 \\
3.36 \\
3.64 \\
3.45 \\
3.51 \\
3.08 \\
3.49\end{array}$ & $\begin{array}{l}0.68 \\
0.60 \\
0.63 \\
0.73 \\
0.73 \\
0.92 \\
0.72\end{array}$ & 6.843 & .000 & $6 / 3$ \\
\hline F4. Affective image & $\begin{array}{l}\text { 1. CEA } \\
\text { 2. A } \\
\text { 3. CBI } \\
\text { 4. CSHU } \\
\text { 5. CSA } \\
\text { 6. CAP } \\
\text { Total }\end{array}$ & $\begin{array}{r}188 \\
88 \\
158 \\
122 \\
148 \\
63 \\
767\end{array}$ & $\begin{array}{l}3.26 \\
3.26 \\
3.46 \\
3.35 \\
3.43 \\
3.05 \\
3.33\end{array}$ & $\begin{array}{l}1.04 \\
0.87 \\
0.71 \\
0.98 \\
0.86 \\
0.95 \\
0.91\end{array}$ & 2.578 & .025 & $6 / 3,5$ \\
\hline $\begin{array}{l}\text { Global indicator of } \\
\text { university organizational } \\
\text { image }\end{array}$ & $\begin{array}{l}\text { 1. CEA } \\
\text { 2. A } \\
\text { 3. CBI } \\
\text { 4. CSHU } \\
\text { 5. CSA } \\
\text { 6. CAP } \\
\text { Total }\end{array}$ & $\begin{array}{r}188 \\
88 \\
158 \\
122 \\
148 \\
63 \\
767\end{array}$ & $\begin{array}{l}3.43 \\
3.31 \\
3.55 \\
3.48 \\
3.54 \\
3.32 \\
3.46\end{array}$ & $\begin{array}{l}0.55 \\
0.54 \\
0.50 \\
0.69 \\
0.63 \\
0.64 \\
0.59\end{array}$ & 3.112 & .004 & $2,6 / 3,5$ \\
\hline
\end{tabular}

Source: Own elaboration based on the results of the research.

Note: SD, standard deviation; CEA, economic and administrative sciences; A, arts; CBI, basic sciences and engineering; CSHU, social sciences and humanities; CSA, health sciences; CAP, agricultural sciences.

The reputation of the institution $(F=5.119 ; p=.000)$ is significantly higher in four Institutions of greater tradition and experience in the University: The Institute of Basic Sciences and Engineering (average $=3.68$ ), Institute of Health Sciences (average =3.67), Institute of Social Sciences and Humanities (average $=3.62$ ), and the Institute of Economic Administrative Sciences (average $=3.62$ ).

The institutional maturity $(F=6.843 ; p=.000)$ is significantly higher in the Institute of Basic Sciences and Engineering (average $=3.64$ ). 
The affective image $(F=2.578 ; p=.025)$, i.e., the group of emotions expressed with regard to the HEI, is perceived significantly higher in the Institute of Basic Sciences and Engineering (average $=3.46$ ) and in the Institute of Health Sciences (average =3.43).

Regarding the global university image $(F=3.112 ; p=.004)$, it can be seen that it is significantly higher (positive) in the Institute of Basic Sciences and Engineering (average =3.55) and in the Institute of Health Sciences (average $=3.54$ ).

As shown in Table 12, the perception of the organizational image of a university is identified to be significantly higher mainly in two institutions: Basic sciences and engineering and Health sciences. These results could be due to the fact that both institutes have a broad trajectory, excellent infrastructure, an outstanding group of full-time professors, and education programs of academic excellence, which together are factors that impact on the perception of the university image to be more positive.

\section{Conclusions}

The objective of this investigation was to evaluate the organizational image of a university with a sample of professors and students from a HEI. To this end, the adaptation of the organizational image scales of Beerli et al. (2002) and Russell and Pratt (1980) to the Mexican population was carried out. The results obtained allow the confirmation of the presence of four factors (three cognitive image factors and one affective image factor) with adequate levels of validity and reliability. In addition, significant correlations were identified for the reactants with their factor and with the total of the scale, as well as significant correlations between the factors of the scale. With these results, it can be stated that there is a scale that complies with the adequate levels of validity and reliability to measure the organizational image of HEIs and universities.

Furthermore, statistically significant differences were identified for the perceived organizational image of each of the schools of the HEI, which indicates that each of them possess different levels in the organizational image of a university (cognitive, affective, and global) as a result of the perception held by both students and professors regarding academic, administrative, and organizational aspects of the evaluated HEI.

In the future, it is recommended to evaluate the organizational image in other educational institutions at the high school, bachelor, and postgraduate levels in order to provide feedback to this type of organizations.

While this investigation was focused in evaluating the organizational image of a university of a HEI, it is recommended that future investigations focus in the management of the image, a process that must be based in the image constructed by the organization and its impact on various audiences (employees, students, suppliers, government, society).

\section{Appendix 1.}

University Organizational Image Scale. Based on the adaptation of Beerli et al. (2002) and Russell and Pratt (1980) to Mexican population. 


\begin{tabular}{|c|c|c|c|c|c|c|c|}
\hline \multicolumn{8}{|c|}{ What is the image you have of this University, Institute or School? } \\
\hline 1 & The teaching of teachers is good & 5 & 4 & 3 & 2 & 1 & The teaching of teachers is bad \\
\hline 2 & Education is good & 5 & 4 & 3 & 2 & 1 & Education is bad \\
\hline 3 & Teachers are very demanding & 5 & 4 & 3 & 2 & 1 & Teachers are not very demanding \\
\hline 4 & Student-centered & 5 & 4 & 3 & 2 & 1 & Not student-centered \\
\hline 5 & Close to the students & 5 & 4 & 3 & 2 & 1 & Away from the students \\
\hline 6 & It is an innovative university & 5 & 4 & 3 & 2 & 1 & It is a traditional university \\
\hline 7 & It is an updated university & 5 & 4 & 3 & 2 & 1 & Is a university not updated \\
\hline 8 & It has a good prestige & 5 & 4 & 3 & 2 & 1 & Has a bad reputation \\
\hline 9 & Has a good reputation & 5 & 4 & 3 & 2 & 1 & Has a bad reputation \\
\hline 10 & It has good facilities & 5 & 4 & 3 & 2 & 1 & It has bad facilities \\
\hline 11 & It has a great variety of educational programs & 5 & 4 & 3 & 2 & 1 & It has few educational programs \\
\hline 12 & Environment is good & 5 & 4 & 3 & 2 & 1 & Environment is bad \\
\hline \multicolumn{8}{|c|}{ How is this University, Institute or School? } \\
\hline 13 & It is a stimulating institution & 5 & 4 & 3 & 2 & 1 & It's a boring institution \\
\hline 14 & It is a relaxing Institution & 5 & 4 & 3 & 2 & 1 & It is a stressful Institution \\
\hline \multicolumn{8}{|c|}{ How do you think it is the general image of this University, Institute or School? } \\
\hline 15 & It is a very positive Institution & 5 & 4 & 3 & 2 & 1 & It is a very negative Institution \\
\hline
\end{tabular}

\section{References}

Baker, S., \& Brown, B. (2007). Images of excellence: Constructions of institutional prestige and reflections in the university choice process. British Journal of Sociology of Education, 28, 377-391. http://dx.doi.org/10.1080/ 01425690701253455

Beerli, A., Díaz, G., \& Pérez, P. (2002). The configuration of the university image and its relationship with the satisfaction of students. Journal of Educational Administration, 40, 486-505. http://dx.doi.org/10.1108/09578230210440311

Berg, P. (1985). Organization change as a symbolic transformation process. In P. Frost, L. Moore, M. Meryl, C. Lundberg, \& J. Marton (Eds.), Organizational culture. California: Sage.

Blázquez, M., \& Peretti, M. (2012). Modelo para gestionar la sustentabilidad de las organizaciones a través de la rentabilidad, adaptabilidad e imagen. Estudios Gerenciales, 28, 40-50. http://dx.doi.org/10.1016/S0123-5923(12)70006-2

Brown, R., \& Mazzarol, T. (2009). The importance of institutional image to student satisfaction and loyalty within higher education. Higher Education, 58, 81-95. http://dx.doi.org/10.1007/s10734-008-9183-8

Chun, R. (2005). Corporate reputation: Meaning and measurement. International Journal of Management Review, 7 , 91-109. http://dx.doi.org/10.1111/j.1468-2370.2005.00109.x

Dichter, E. (1985). What's in an image. The Journal of Consumer Marketing, 2, 75-79. http://dx.doi.org/10.1108/eb038824

Druteikiene, G. (2011). University image: Essence, meaning, theoretical and empirical investigation. Global Conference on Business and Finance Proceedings, 6, 167-174.

Dukerich, J., Golden, B., \& Shortell, S. (2002). Beauty is in the eye of the beholder: The impact of organizational identification, identity, and image on the cooperative behaviors of physicians. Administrative Science Quarterly, 47, 507-533. http://dx.doi.org/10.2307/3094849

Duque, O. E., \& Carvajal, P. L. (2015). La identidad organizacional y su influencia en la imagen: una reflexión teórica. Suma de Negocios, 6, 114-123. http://dx.doi.org/10.1016/j.sumneg.2015.08.011

Dutton, J., Dukerich, J., \& Harquail, C. (1994). Organizational images and member identification. Administrative Science Quarterly, 39, 239-263. http://dx.doi.org/10.2307/2393235

Fombrun, C., \& Van Riel, C. (2003). Fame \& fortune: How successful companies build winning reputations. New Jersey: Editorial Prentice Hall.

Galiniené, B., Marcinskas, A., Miskinis, A., \& Druteikiene, G. (2009). The impact of study quality on the image of higher education institution. Informacijos Mokslal, 48, 68-81.

Giangrande, V. (1995). Em defesa do consumidor. Revista de Comunicação, 40, 20-21.

Gioia, D., \& Thomas, J. (1996). Identity, image, and issue interpretation: Sensemaking during strategic change in academia. Administrative Science Quarterly, 41, 370-403. http://dx.doi.org/10.2307/2393936 
Guédez, F. C., \& Osta, T. K. M. (2012). Factores del a imagen institucional universitaria: Perspectiva desde el sector del público interno, personal administrativo. Revista Ingeniería Industrial, 11, 71-84.

Guerra, V., \& Arends, P. (2008). Medición de la imagen institucional de un postgrado universitario. Revista Ingeniería Industrial: Actualidad y Nuevas Tendencias, 1, 10-20.

Günalan, M., \& Ceylan, A. (2014). The mediator role of organizational image on the relationship between jealousy and turnover intention: A study on health workers. The Journal of Social Sciences Institute, 17, 133-156.

Helgesen, O., \& Nesset, E. (2007). Images, satisfaction and antecedents: Drivers of student loyalty? A case study of a Norwegian University College. Corporate Reputation Review, 10, 38-59. http://dx.doi.org/10.1057/palgrave.crr.1550037

Herrbach, O., \& Mignonac, K. (2004). How organizational image affects employee attitudes. Human Resource Management Journal, 14, 76-88. http://dx.doi.org/10.1111/j.1748-8583.2004.tb00134.x

Huang, C., \& Lien, H. (2012). An empirical analysis of the influences of corporate social responsibility on organizational performance of Taiwan's construction industry: Using corporate image as a mediator. Construction Management and Economics, 30, 263-275. http://dx.doi.org/10.1080/01446193.2012.668620

Kotler, P. (1975). Marketing for non-profit organizations. New Jersey: Editorial Prentice-Hall.

Kotler, P., \& Andreasen, A. (2008). Positioning the organization: Strategic marketing for nonprofit organizations. New Jersey: Editorial Prentice-Hall.

Mael, F., \& Ashforth, B. (1992). Alumni and their alma mater. A partial test of the reformulated model of organizational identification. Journal of Organizational Behavior, 13, 103-123. http://dx.doi.org/10.1002/job.4030130202

Magierski, D., \& Kassouf, N. (2003). Análise da imagen organizacional de universidades por meio da matriz familiaridadefavorabilidade. Revista de Administração Mackenzie, 4, 25-37.

McPherson, M., \& Schapiro, M. (1998). The student aid game. New Jersey: Princeton University Press.

Nguyen, N., \& Leblanc, G. (2001). Image and reputation of higher education institution in student's retentions decisions. The International Journal of Educational Management, 15, 303-311. http://dx.doi.org/10.1108/EUM0000000005909

Nolan, K. P., \& Harold, C. M. (2010). Fit with what? The influence of multiple self-concept images on organizational attraction. Journal of Occupational and Organizational Psychology, 83, 645-662. http://dx.doi.org/ $10.1348 / 096317909 X 465452$

Perozo, J. G., \& Alcalá, S. M. (2008). Imagen corporativa de los Institutos Tecnológicos Universitarios de Maracaibo. Multiciencias, 8, 105-112.

Polat, S. (2011). The relationship between university students' academic achievement and perceived organizational image. Educational Sciences: Theory \& Practice, 11, 257-262, 10.16 Kocaeli University.

Russell, J. A., \& Pratt, G. (1980). A description of the affective quality attributed to environments. Journal of Personality and Social Psychology, 38, 311-322. http://dx.doi.org/10.1037/0022-3514.38.2.311

Sartore-Baldwin, M.-L., \& Walker, M. (2011). The process of organizational identity: What are the roles of social responsiveness, organizational image, and identification? Journal of Sport Management, 7, 489-505. http://dx.doi.org/10.1057/crr.2008.23

Stevens, R., McConkey, W., Cole, H., \& Clow, K. (2008). College image: A strategy marketing dilemma. Services Marketing Quarterly, 29, 99-113. http://dx.doi.org/10.1080/15332960802126005

Torpor, B. (1983). Athletics and marketing. Marketing Higher Education, IX, 6.

Toto, M. F., \& García, L. T. (2012). Vinculación, imagen y posicionamiento de una IES en la región de San Andrés Tuxtla, Veracruz. Ciencia Administrativa, 2, 11-24.

Traverso, C. J. (2005). Imagen interna de la institución universitaria. Modelo para el personal de administración y servicios. Revista de Economía y Empresa, XXIII(54 and 55), 95-112.

Treadwell, D., \& Harrison, T. (1994). Conceptualizing and assessing organizational image: Model, images, commitment, and communication. Communication Monographs, 61, 63-85. http://dx.doi.org/10.1080/03637759409376323

Yim, Y., \& Schafer, B. (2009). Police and their perceived image: How community influence officers' job satisfaction. Police Practice and Research, 10, 17-29. http://dx.doi.org/10.1080/15614260802128658 